\title{
Depredation in gillnets operated along the south-west coast of India
}

\author{
S. CHINNADURAI, PARAS NATH JHA, R. K. RENJITH, M. P. REMESAN, SALY N. THOMAS \\ AND M. V. BAIJU \\ ICAR-Central Institute of Fisheries Technology, Kochi - 682 029, Kerala, India \\ e-mail: chinnaduraitvl@gmail.com
}

\section{ABSTRACT}

Experimental gillnet (polyamide, $210 \mathrm{~d} \times 9 \times 3$ with $140 \mathrm{~mm}$ mesh size) fishing was conducted onboard FV Sagar Harita $\left(\mathrm{L}_{\mathrm{OA}} 19.5 \mathrm{~m}\right)$ during September, 2016. Out of six sets deployed, three incidents of depredation, possibly by puffer fish were observed, when $41.5,33.7$ and $40 \%$ of the catch was lost. Depredation could be prevented effectively by frequent monitoring of the deployed gillnets at shorter intervals. Studies on depredation with special reference to soaking time, hauling speed, seasonal variation and location of fishing grounds are needed in view of the economic losses incurred.

Keywords: Catch, Depredation, Fishing, Food loss, Predator, Puffer fish

Food loss and its quantification is one of the most challenging tasks in capture fisheries. Understanding of losses is a critical step towards better fisheries management. The causes for the food loss are usually loss of gear, lack of proper storage, non-targeted catch, adverse weather, no market demand and depredation (FAO, 2017). Depredation is defined as partial or complete removal of catch from the fishing nets by predators (Romanov et al., 2009). Though it has been well documented in longline fishery (Garrison, 2007), very little information is available for gillnets. Sharks and cetaceans are the major predators reported in artisanal fishing gears (Konigson et al., 2007; Brotons et al., 2008; Rafferty et al., 2012; Cosgrove et al., 2015).

Experimental fishing was conducted onboard FV Sagar Harita $\left(\mathrm{L}_{\mathrm{OA}} 19.5 \mathrm{~m}\right)$ during September, 2016 using multifilament gillnets made of polyamide $(\mathrm{PA})(210 \mathrm{~d} \times 9 \times 3)$ with $140 \mathrm{~mm}$ mesh size. The nets were of $1990 \mathrm{~m}$ length and 104 meshes deep rigged at 0.5 hanging coefficient. The depth of operation ranged between 35 and $50 \mathrm{~m}$. Six sets of nets were deployed between 17.30 and $18.00 \mathrm{hrs}$. Soaking time of the net ranged from 3 to $5 \mathrm{~h}$ (Table 1).
Target species of experimental gillnets were large pelagics. Scomberomorus guttatus dominated the catch $(29.42 \%)$, followed by Sphyraena jello (26.47\%), Rachycentron canadam (13.23\%), Megalaspis cordyla (8.45\%), Rastrelliger kanagurta (8.09\%) and miscellaneous fishes (14.28\%). Targeted and bycatch species contributed 74.5 and $25.5 \%$ of the total catch respectively.

The present experiment coincided with the season when puffer fish abundance was expected to be the highest in the south-west coast of India (Mohamed et al., 2013). Out of six sets deployed, three $(50 \%)$ incidents of depredation, possibly by puffer fish, were observed during the study. The assumed weight (W) of each fish prior to predation, was estimated from mass (W) - length (L) equations described by Rafferty et al. (2012). It was observed that $41.5,33.7$ and $40 \%$ of the catch was lost due to depredation in three fishing operations, respectively. Comparative analysis showed that Indian mackerel and carangids were the most affected by depredation. It was estimated that depredation led to an average economic

Table 1. The geographical position of the study area, depth of operation, soaking time and depredation loss observed in gillnets

\begin{tabular}{|c|c|c|c|c|c|}
\hline Date & Latitude & Longitude & Depth (m) & Soaking time (h) & Depredation (\%) \\
\hline 06.09 .2016 & $09^{\circ} 47^{\prime} 056^{\prime \prime} \mathrm{N}$ & $076^{\circ} 02^{\prime} 083^{\prime \prime} \mathrm{E}$ & 40 & 5 & 0 \\
\hline 09.09 .2016 & $09^{\circ} 48^{\prime} 051^{\prime \prime} \mathrm{N}$ & $076^{\circ} 04^{\prime} 043^{\prime \prime} \mathrm{E}$ & 35 & 4.5 & 41.5 \\
\hline 19.09 .2016 & $09^{\circ} 46^{\prime} 076^{\prime \prime} \mathrm{N}$ & $076^{\circ} 00^{\prime} 067^{\prime \prime} \mathrm{E}$ & 45 & 3 & 33.7 \\
\hline 21.09 .2016 & $09^{\circ} 500^{\prime} 001^{\prime \prime} \mathrm{N}$ & $076^{\circ} 00^{\prime} 013^{\prime \prime} \mathrm{E}$ & 40 & 3 & 40.0 \\
\hline 23.09 .2016 & $09^{\circ} 48^{\prime} 051^{\prime \prime} \mathrm{N}$ & 0755'010’'E & 50 & 3 & 0 \\
\hline 26.09.2016 & $09^{\circ} 43^{\prime} 054^{\prime \prime} \mathrm{N}$ & $076^{\circ} 03^{\prime} 007^{\prime \prime} \mathrm{E}$ & 50 & 3 & 0 \\
\hline
\end{tabular}


loss of ₹ 150 per $1,000 \mathrm{~m}$ of net which represents $5.19 \%$ of the catch value.

The pattern of bites mainly on anterio-dorsal portion of fishes clearly indicate depredation causing the removal of flesh from the fish caught in the net (Fig. 1). The mean weight of damaged fish was highest on 09 Septembewr 2016 (41.5\%). Mean size of depredated and undamaged fishes were similar in all instances. No substantial difference in size of damaged and undamaged fish caught in the gear was noted. The overall proportion of depredated Indian mackerel in the current study (18\%) was considerably higher than carangids (10.9\%).

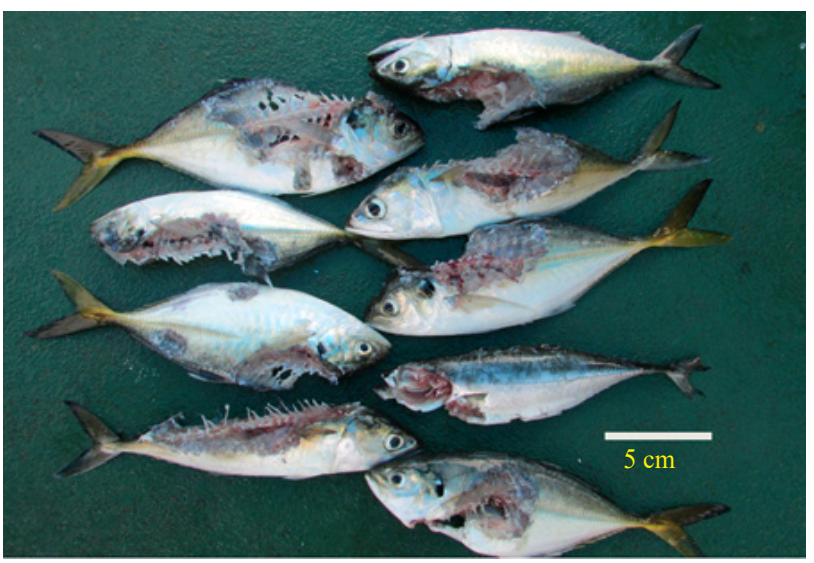

Fig. 1. Depredation observed in the catches of Indian mackerel and carangids caught in gillnets off Kochi

The most common puffer species encountered during fishing activity are Lagocephalus inermis, Arothron sp., and Diodon sp. (Raphael et al., 2017). Damage caused by puffer fish to the catch and gear potentially poses threat to the livelihood of coastal fishermen. However, very little quantitative information is available in this regard (Mohamed et al., 2013). The major constraints due to depredation are the substantial loss of catch, the time required to repair damaged gear and loss of gear. Depredation by puffer fish often results in damage to a sizeable quantity of the net also. Puffer fish taken as bycatch in trawls are also responsible for damage to other catch already caught (Mohamed et al., 2013). A growing body of information concerning the operational interactions between puffer fish and fishing gear has been emerging in India, post-tsunami period (Raphael et al., 2017). Depredation in gillnets and significant damage to gillnet operations by harbour seal and spiny dog fish was reported in George Bank (Rafferty et al., 2012). Konigson et al. (2007) reported that due to depredation almost half of the catch (42\%) is lost from herring gillnet fisheries in northern Baltic Sea. Depredation rate by bottlenose dolphin (Tursiops truncatus) was nearly 13\% in artisanal fisheries around the Balearic Islands (Brotons et al., 2008). For bottom-set gillnet in Irish waters, the depredation rate was upto 29\% (Cosgrove et al., 2015). Understanding the factors contributing to interactions between predators and gillnet is essential for reducing depredation and the damage to gear in gillnet fishing operations.

Incidents of killer whale and shark depredation in longline fishery has been reported from the Indian EEZ (Varghese et al., 2008; Kumar et al., 2016). The first report of depredation in gillnet fishery in India was on depredation by crabs in Lakshadweep waters (Sherief et al., 2015). However, the present study is the first report on quantification of catch loss in Indian gillnet fishery due to depredation. The economic loss by depredation in both artisanal and mechanised gillnet fisheries in Indian waters needs special attention.

Soaking time in the case of gillnet fisheries is found to be a significant factor for depredation and can be controlled by simple operational interventions. Depredation could be prevented effectively by frequent monitoring of the deployed gillnets at shorter intervals. Further studies are needed on depredation in gillnets, with special reference to soaking time, hauling speed, seasonal variation and location of fishing grounds.

\section{Acknowledgements}

Authors express thanks to the Director, ICAR-CIFT, Kochi for the facilities and encouragement. The authors are also indebted to Dr. E. Vivekanandan, for his valuable advice. The help rendered by the skipper and crew members of F. V. Sagar Harita is gratefully acknowledged.

\section{References}

Brotons, J. M., Grau, A. M. and Rendell, L. 2008. Estimating the impact of interactions between bottlenose dolphins and artisanal fisheries around the Balearic Islands. Mar. Mammal Sci., 24(1): 112-127. https://doi.org/10.1111/j.17 48-7692.2007.00164.x.

Cosgrove, R., Gosch, M., Reid, D., Sheridan, M., Chopin, N., Jessopp, M. and Cronin, M. 2015. Seal depredation in bottom-set gillnet and entangling net fisheries in Irish waters. Fish. Res., 172: 335-344. https://doi.org/10.1016/j. fishres.2015.08.002.

FAO 2017. FAO Fisheries and aquaculture proceedings. In: Suuronen, Petri Siar, Susana V., Leela Edwin, Saly N. Thomas, Pravin, P. and Gilman Eric (Eds.), Proceedings of the report of the expert workshop on estimating food loss 
and wasted resources from gillnet and trammel net fishing operations, 8-10 April 2015, Kochi, India, 99 pp.

Garrison, L. P. 2007. Interactions between marine mammals and pelagic longline fishing gear in the U. S. Atlantic Ocean between 1992 and 2004. Fishery Bull., 105(3): 408-417.

Konigson, S., Fjalling, A. and Lunneryd, S. 2007. Grey seal induced catch losses in the herring gillnet fisheries in the northern Baltic. NAMMCO Scientific Publications, 6: 203-213. doi.org/10.7557/3.2735.

Kumar, A., Pravin, P. and Bharathiamma, M. 2016. Bait, bait loss and depredation in pelagic longline fisheries - A review. Rev. Fish. Sci. Aquac., 24(4): 295-304. https://doi.org/10. 1080/23308249.2016.1162134.

Matsuura, K. 2015. Taxonomy and systematics of tetraodontiform fishes: a review focusing primarily on progress in the period from 1980 to 2014. Ichthyol. Res., 62: 72-113. https://doi.org/10.1007/s10228-014-0444-5.

Mohamed, K. S., Sathianandan, T. V., Kripa, V. and Zacharia, P. U. 2013. Puffer fish menace in Kerala : a case of decline in predatory control in the south-eastern Arabian Sea. Curr. Sci., 104(4): 426-429.
Rafferty, A. R., Jr, E. O. B. and Reina, R. D. 2012. Depredation by harbour seal and spiny dogfish in a Georges Bank gillnet fishery. Fish. Manage. Ecol., 19: 264-272. https://doi.org/ 10.1111/j.1365-2400.2011.00837.x.

Raphael, L., Joseph, R. and Edwin, L. 2017. Depredation and catch loss due to the interaction of aquatic organisms with ring seines off Cochin region. Fishery Technol., 54: 66-70.

Romanov, E., Pascal, B. and Njaratiana, R. 2009. Depredation -Improvement of the information flow within IOTC 1. Draft IOTC information sheet, reporting form and webpage. IOTC-2009-WPEB-04. IOTC Working Party on Ecosystems and Bycatch (WPEB), 12-14 October 2009, Mombasa, Kenya, 13 pp.

Sherief, P. S. M., Das, P. H. D., Thomas, S. N. and Edwin, L. 2015. Food loss from gillnets operated in Lakshadweep waters. Fish. Tech. Reporter, I(2): 16-17.

Varghese, S., Somvanshi, V. S. and Varghese, S. P. 2008. Depredation in the longline fishery of the Indian waters, Fishery Survey of India, Dept. of Animal Husbandry, Dairying and Fisheries, Ministry of Agriculture, Govt. of India, Mumbai, 28 pp. 